\title{
Publishing science in the digital age. The case of Neurocirugía
}

\author{
S.S. Izquierdo, L.R. Izquierdo* and J.M. Izquierdo** \\ University of Valladolid (Spain). *University of Burgos (Spain). **Centro Médico de Asturias (Spain).
}

\section{Summary}

Neurocirugía publishes a printed edition for subscribers, and also an electronic edition which is available online free of charge. The coexistence of these two formats raises some issues regarding their justification and their future evolution, e.g. why does a subscription-based journal offer free online access? Would it be wise to charge for -or somewhat limit- the electronic access to the Journal? How is the Internet changing the benefits to society that the Journal provides? Will the printed and the electronic edition of the Journal continue to coexist? This paper provides some answers and reflections on these questions. Many of our considerations are based on ideas that have been presented and discussed in a series of editorials in Neurocirugía (see Neurocirugía 17 (2), 2006); in this paper we reconsider, complement, and rearrange previous arguments to address the issues mentioned above. Based on an analysis of economic costs and of all the stakeholders involved (authors, readers, the Journal, the Spanish Society of Neurosurgery, and society as a whole), we justify the present coexistence of the two publishing formats, defend free online access, and provide our view on the expected evolution of the Journal. While we focus primarily on Neurocirugía, most of our reflections can be carried over to other scientific journals.

Las publicaciones científicas ante la era digital. El caso de Neurocirugía

\section{Resumen}

Neurocirugía publica una edición impresa por suscripción y una edición electrónica en Internet de acceso gratuito. La convivencia de estos dos esquemas plantea algunos interrogantes sobre su justificación y sobre su evolución esperada, tales como ¿Por qué un acceso de pago y otro gratuito? ¿Conviene cobrar o

Recibido: 20-08-06. Aceptado: 10-01-07 limitar el acceso electrónico? ¿Cómo cambia Internet el servicio a la sociedad que proporciona la revista? ¿Seguirán conviviendo la versión impresa y la electrónica? En este artículo presentamos algunas respuestas y reflexiones sobre las preguntas anteriores. Muchas de estas reflexiones se basan en ideas presentadas y discutidas en editoriales previos de Neurocirugía (ver Neurocirugía 17 (2), 2006), y son aquí reorganizadas, reenfocadas o complementadas de forma conveniente para responder a los interrogantes planteados. A partir de un análisis de costes y beneficios para los distintos agentes implicados (autores, lectores, la propia revista, la Sociedad Española de Neurocirugía, la sociedad en su conjunto), justificamos la coexistencia actual de los dos esquemas de publicación, defendemos el acceso gratuito por Internet, y exponemos nuestra visión sobre la evolución esperada. Si bien nos centramos particularmente en Neurocirugía, la mayoría de las consideraciones realizadas son extensibles a la publicación y al futuro esperado de otras revistas científicas.

La versión completa de este artículo en castellano se encuentra disponible en la edición electrónica de Neurocirugía en http://revistaneurocirugia.com

\section{Introduction}

The importance of writing in human history is difficult to overestimate: History begins with writing. Since then, almost everything that humankind has ever learnt -all our knowledge- has been documented, archived, and transmitted through the countless combinations of a comparatively small number of graphical symbols (in most languages, letters). Such arrangements of symbols encode knowledge into books and journals in a way that somewhat resembles how nucleotides encode genetic information in DNA chains. Similarly, as the genome is, to a certain extent, the memory of a species (as it houses and concentrates all the modifications that evolution has printed on the genetic makeup of the species), so are books and journals the memory of civilisations, as they also house and condense everything that humankind has learned since the appear- 
ance of the written word.

Books and journals could be seen, therefore, as the genome of the culture and memory of a civilisation. It is genome in the sense that sufficient information to start up an entire civilisation from scratch is condensed into a minimal space. Using this information, which can be coded in sequences of just a few symbols appropriately arranged in precise ways, humankind is able to develop enterprises, build factories, and cure diseases. Different books provide information about different scientific disciplines and arts, just like different sequences of the genome contain distinct information about how specific organs and systems are to be formed and developed.

So far we have pointed out static aspects of similarity only, but the analogy extends well to encompass the processes that govern the dynamics of change, i.e. the evolution of scientific knowledge: in the same way as the genome is the vehicle of transmission for the "evolutionary memory of a species" throughout generations, so are books and journals one of the primary vehicles of transmission for our existing knowledge. As for the evolution and creation of new knowledge, historically this process has been conducted by refining and combining different pieces of preexisting knowledge, and potentially complementing these with novel sparks of intellectual illumination and original experimentation. Such innovative sparks can be seen as mutations added to the otherwise pure process of selection and recombination of previous knowledge.

Thus, it seems that, in a way, knowledge has been following -and still follows- its own evolutionary process*, with the printed letter -in the form of books and journalsbeing one of the main physical structures through which this evolutionary process has been taking place throughout History.

Only recently a new physical substrate for our knowledge, the digital media, has become widely available in a world previously dominated by paper and ink. The advent of the Digital Age is bound to change the evolution of knowledge in unprecedented ways. While it takes days for knowledge to travel from one location to another in the form of printed material, it takes only seconds when this is done in electronic format. The new "genetic substrate" does not only increase the speed of transmission by many orders of magnitude, it also decreases the costs of replication in similar proportions.

\footnotetext{
* The analogy between scientific progress and genetic evolution was greatly enlightened by Sir Karl Popper, and is the object of study in the Evolutionary Epistemology of Theories². The (more general) analogy between cultural and genetic evolution was put forward by Richard Dawkins ${ }^{5}$ and led to the "memetics movement".
}

It seems clear then that the current potential to publish using electronic media has remarkable implications for the future evolution of scientific knowledge. In the particular context of our Journal, Neurocirugía, we are in a privileged position in that we can somewhat drive this process of evolution to meet our various stakeholders' best interests by controlling the way in which the Journal is published. Neurocirugia, as you all know, has been published both in paper and electronically for a number of years. In this paper we justify the present coexistence of these two publishing formats, defend free online access, and provide our view on the expected evolution of the printed and electronic editions of the Journal.

For the sake of clarity, we have structured the rest of the paper following a question-and-answer scheme. The answer to the first question, "Why does a subscriptionbased journal offer free online access?", provides an analysis of the economic costs involved in the printed and in the electronic edition; this analysis is then used to explain why the printed edition could not be freely distributed, even if desired, but it is indeed financially feasible to give free online access to the electronic edition. Having established the economic viability of providing free online access to Neurocirugia, the second question, "Would it be wise to charge for -or somewhat limit- the electronic access to the Journal?", discusses whether free access is a desirable goal for the various stakeholders of the Journal. The third question, "How is the Internet changing the benefits to society that the Journal provides?", is a reflexion on the social service that scientific journals (in general) provide, given that nowadays scientists do not depend on these journals to make their papers widely available as strongly as in the past. The last question, "Will the printed and the electronic edition of the Journal continue to coexist?", presents our views on the expected evolution of the printed and electronic editions of the Journal. Finally, we provide some conclusions.

\section{Why does a subscription-based journal offer free online access?}

In the next section we extensively argue that making Neurocirugia freely available to readers worldwide is in the best interest of authors and society in general, and it is the dissemination policy that best achieves the objectives of Neurocirugía. Here, we explain why giving free access to the electronic edition of the Journal can be economically feasible, whilst providing printed issues free of charge cannot.

As Lobato et al. ${ }^{15}$ point out, the costs incurred in producing the printed edition and those required for the electronic version are different in nature. Offering the printed edition free of charge is not economically feasible, since 


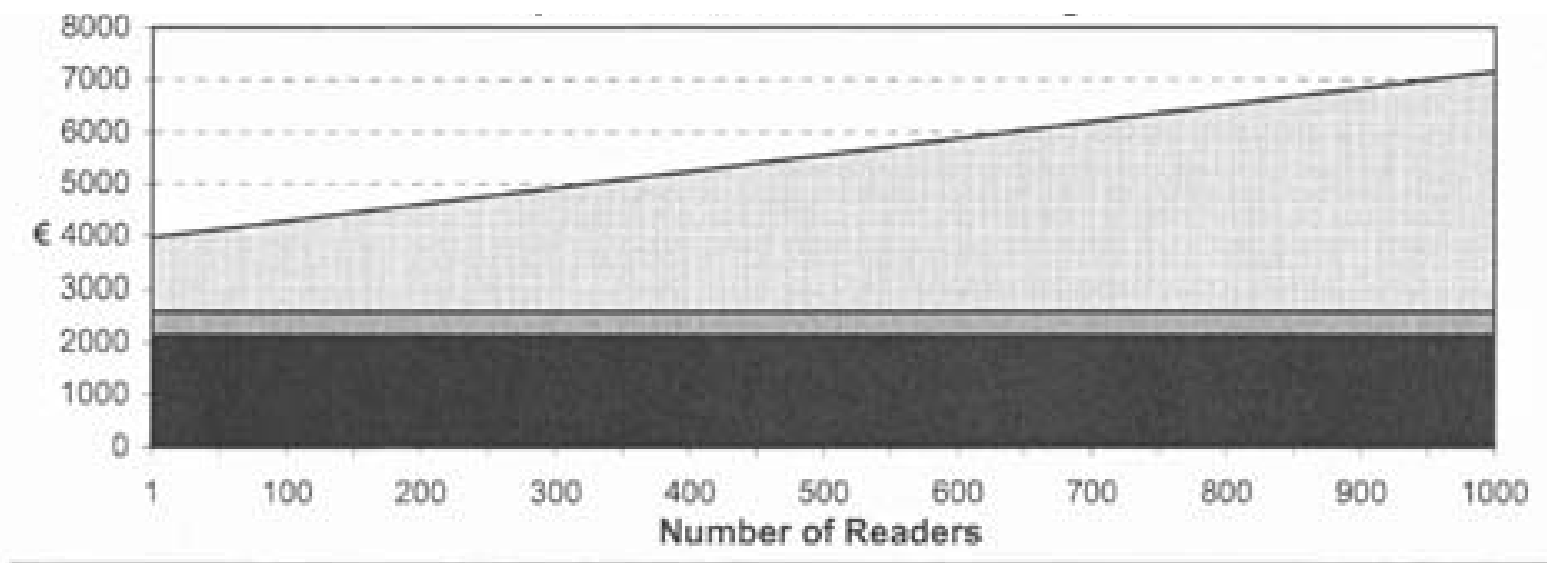

Figure 1. Approximate costs (excluding VAT) involved in the composition, reproduction, and distribution of a representative issue of Neurocirugia, as a function of the number of readers. The estimates have been calculated assuming the issue comprises 96 black and white pages.

there are significant printing and distribution costs involved in creating and delivering individual issues to new potential readers (these are called marginal costs). On the contrary, the costs of the electronic edition are independent of the number of readers; once the journal is in electronic format, it can be made freely available to readers worldwide without any effect on costs: the marginal cost of a new reader is zero ${ }^{21}$ (Figure 1).

Does this mean that the electronic edition of the Journal is significantly cheaper? The answer to this question depends on the type of costs we consider and on the number of readers (or, more precisely, the number of individual printed issues). Considering only the costs incurred by the Journal, the electronic edition is indeed significantly cheaper than its printed counterpart, and this difference increases with the number of printed issues (see Figure 1). Having said that, when considering the whole publishing process, there are various costs that are not incurred by the Journal and all of these are basically the same regardless of whether the Journal is printed or not: in general, publishing a paper requires the elaboration and writing of the manuscript, its review, the corrections, its composition, reproduction and distribution, its dissemination and indexing (e.g. submitting the paper and its metadata to electronic databases like PubMed or SciELO in the requested format), its archiving and, of course, the management and coordination of this whole process. All these stages entail costs and, with the exception of those associated with the reproduction and distribution of the papers, they are all approximately the same independently of the chosen format(s).

At present, nearly all costs incurred by the Journal derive from the composition, reproduction, and distribution of its papers. Figure 1 shows the approximate cost of these activities. As indicated before, the crucial difference between the reproduction and distribution costs of the printed edition and the corresponding costs in the electronic version is that the former increase with the number of readers whereas the latter do not. Representative values of these costs for other journals are provided by Odlyzko ${ }^{16}$ and $\operatorname{Varian}^{22}$.

\section{Would it be wise to charge for -or somewhat limit- the electronic access to the Journal?}

A subscription to access the electronic edition of the Journal or any other pricing scheme (e.g. see those considered in the experiment "Pricing Electronic Access to Knowledge" , by the University of Michigan) would provide an income to the Journal, but they would also limit its dissemination. This measure would have diverse consequences for the various stakeholders with an interest in the work submitted to the Journal and in its publication; namely the authors, the Journal as an organisation with its own objectives, and society in general.

Assuming that authors do not obtain any financial benefit from sales of the journals that publish their papers -as it is usual in research-, their main objective is often to maximise the dissemination of their work. An arguably related objective is to publish in high impact factor journals, since this index is often used -wrongly or not, as discussed by Sahuquillo ${ }^{18}$ - to assess the quality of their research. Consequently, it is in the authors' best interest to make the Journal widely and freely available, as this policy favours higher dissemination and higher impact factors (see for instance the study of Lawrence ${ }^{14}$ on the relation between free online availability and a paper's impact). 
Table 1

Impact factor of Neurocirugía from 1995 to 2005. Source: JCR

\begin{tabular}{|l|l|l|l|l|l|l|l|l|l|l|l|}
\hline Year & 1995 & 1996 & 1997 & 1998 & 1999 & 2000 & 2001 & 2002 & 2003 & 2004 & 2005 \\
\hline Impact Factor & .069 & .051 & .124 & .057 & .185 & .154 & .130 & .244 & .202 & .299 & .232 \\
\hline
\end{tabular}

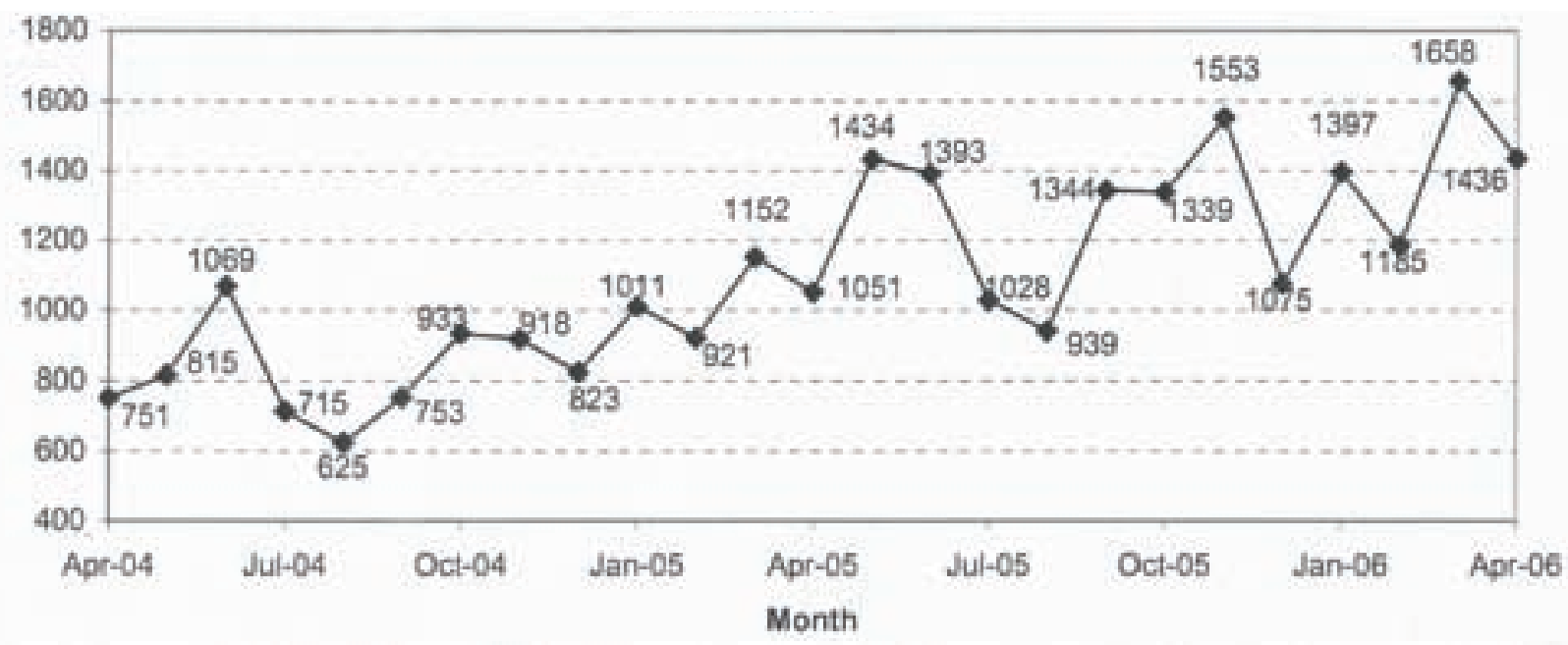

Figure 2. Number of monthly visits from PubMed to papers published online in Neurocirugía. Source: PubMed.

From the perspective of Neurocirugia, the question is whether making electronic access subject to payment further enhances the objectives of the Journal. The main objective of Neurocirugía is to disseminate relevant neurosurgical research: original papers, clinical notes, reviews, and commentaries in the areas of pathology related to the Neurosurgical Sciences. There is little doubt that providing free online access enhances the dissemination of the Journal and increases its impact factor ${ }^{10,14}$. Thus, in pursuing its objectives, Neurocirugía has been publishing online and free of charge all its abstracts and a selected number of papers since 1996, and the full content of all its papers since 2001. Neurocirugía's website also includes a search engine that operates on all its papers. Ibáñez et al. ${ }^{12}$ remind us that the JCR impact factor of a particular year only considers citations to papers published in the Journal in the two preceding years: thus, to improve the value of this index, the references of an article must include citations to papers published in the two previous years. It is therefore crucial to give wide visibility and speedy access to the papers published in the Journal ${ }^{6}$, a goal strongly related to the speed of the editorial process, the development of effective search engines, the inclusion of the Journal in databases such as PubMed (which comprises MEDLINE) ${ }^{6}$, and the immediate availability of the full content of papers on the Internet. These factors are important in capturing citations that can increase the impact factor. A high impact factor makes the Journal more attractive for authors, something that leads to more and better quality submissions; a greater pool of manuscripts to select from allows for an increase in the quality of published papers and, in this way, it potentially creates a positive feedback on the value of the impact factor. Ibáñez ${ }^{11}$ attributes the increasing trend of Neurocirugía's impact factor (see table 1) to the Journal's presence in MEDLINE, its free online accessibility from PubMed (see figure 2), and to authors paying more attention to papers published in Neurocirugía when preparing their submissions to the Journal.

Coming back to our analysis of the stakeholders with a potential interest in the research published in Neurocirugia, we now consider society as a whole. From a social point of view, research is a source of advancement and development for humankind; medical research, in particular, impacts on such a valuable good as health. Applied research is often carried out by private enterprises that expect to obtain short or medium-term profits from it. Such expectations are not usually so clear in the case of basic research, where the primary aim is to advance our scientific knowledge. A comparative study of two surgical techniques could save many lives, but an entrepreneur will not necessarily be interested 
in funding such an investigation if there are no expectations for substantial profit. Research is the classical example of an activity that generates social benefits that very often significantly exceed the returns that a private investor could obtain from it. This is the reason why basic research is usually funded and supported by public institutions (though, arguably, this has not typically been the situation encountered by most of the Spanish authors who publish in Neurocirugia). Social aspirations are best fulfilled if the Journal provides the widest possible dissemination of science of the best possible quality, and, as we have previously argued, free open access can help to achieve these goals. An additional implication of this argument is that the Journal is in a better position to apply for public funding if it provides free availability and unrestricted use of its contents, as the social benefit the journal provides is greater in that case.

Looking at the scientific community, there are various initiatives aimed at promoting free access to published work $^{3}$, like the Open Archives Initiative (http: //www.openarchives.org) and, within the medical and biological sciences, the Public Library of Science (PLoS, http: //www.plos.org/) and the digital library PubMed Central of the US National Institutes of Health (http://www.pubmed central.nih.gov/). In many cases, such initiatives go well beyond promoting access free of charge, and they advocate a series of principles known as "Open Access Publishing"; basically, these principles complement free and unrestricted access to the publication with rights to copy it, use it, and distribute it, with the only condition of properly acknowledging the original authorship. The "open letter" put forward by the Public Library of Science states the commitment to "publish in, edit or review for, and personally subscribe to only those scholarly and scientific journals that have agreed to grant unrestricted free distribution rights to any and all original research reports that they have published, through PubMed Central and similar online public resources, within 6 months of their initial publication date". By May 2006 this letter had been signed more than 33000 times. In June 2006 the Directory of Open Access Journals (http: //www.doaj.org) was already reporting more than 2200 journals. Another example is the position statement on access to research outputs of the British Research Councils (the principal investors in publicly-funded research in the UK): in 2005 such statement proposed that research papers arising from Council-funded work should be deposited in openly available repositories at the earliest opportunity (http://www.rcuk.ac.uk/access/).

In conclusion, giving free and unrestricted access to the full contents of the Journal seems to be the best option to promote scientific and social development, and it is also the most desirable option for authors and society as a whole, and the one that is best aligned with the objectives of the
Journal (assuming its economic viability is secured). As explained in the previous section, providing printed issues free of charge is not economically feasible, but giving free access to the electronic edition of the Journal can be indeed financially viable. Nowadays advertising in the printed edition of Neurocirugia provides sufficient income to cover approximately $80 \%$ of the total costs. Thus, it is important to keep looking for new funding opportunities that complement the financial support that the Journal receives from the Spanish Society of Neurosurgery. An alternative solution that has been mentioned before in Neurocirugía $a^{7,15}$ would be setting up an "authors-pay" publication model, in which authors (or their sponsor institutions) pay a proportion of the reviewing and/or publication costs. This model introduces a filter based on funding availability rather than on the scientific quality of the research, and we therefore consider it inappropriate.

\section{How is the Internet changing the benefits to society that the Journal provides?}

The Internet is enabling researchers to become less dependent on scientific journals to make their papers widely available. Thus, given that one of journals' core roles is being substantially undermined, we may wonder what other services scientific journals have to offer in the Digital Age. This section presents some answers to that question and proposes some recommendations for the sustainability of the peer-review system, which is identified as one of the key services that scientific journals provide.

Contrary to what happens with the (wide) dissemination of printed material, the diffusion of electronic documents through the Internet is inexpensive and lacks significant economic or technological barriers; thus, it is generally possible for authors to conduct it themselves. Nowadays most word processors allow for the creation of simple web pages, and many institutions provide the means to place these on the Internet. If institutional support is not available, one can always arrange the creation and hosting of a personal website with a private Internet server for less than $80 € /$ year, and such a website could be shared by multiple authors. Thus, it seems that nowadays authors do not need journals to publicise the results of their research. What is then the added value in dealing with a journal?

For authors, the added value provided by the Journal derives from the prestige and kudos gained when publishing in it, the associated enhancement of their curriculum vitae, the expected improvement in the quality of their work as a result of the review process (arguable as this may $\mathrm{be}^{15,17}$ ), and a greater visibility and dissemination of their work.

For society in general, the Journal provides added value by: 
- Acting as an information filter by selecting the research that is of greatest interest to the readers of the Journal. This is an increasingly important function given the prevalent flood of information on the Internet.

- Conducting a rigorous scientific control on its contents ${ }^{7,13,15}$, and improving the quality of the submitted research through the review process.

- Archiving, preserving, and giving access to the newly developed knowledge. This function includes the assurance that published material will remain unaltered.

A significant part of the social value generated by the Journal is directly or indirectly associated with the review and selection process. This process requires an enormous amount of work, both from the referees and from those who manage and coordinate the whole process (i.e. editorial board, associate editors, and support team), which in most cases remains unpaid. The editorial in volume 17 (2) of Neurocirugía (2006) $)^{7}$ and the papers by Lobato et al. ${ }^{15}$ and Ibáñez ${ }^{11}$ in the same issue highlight the crucial role that referees play in maintaining the quality of the Journal. The report developed by the UK Research Councils on improved access to research outputs (http://www.rcuk.ac.uk/ access/summary.pdf) indicates that "rigorous, high-quality peer review remains the guarantor of quality whatever the medium of publication, and must be the norm as new models develop". It is therefore crucial to devise appropriate mechanisms that ensure a sustainable future for the review process. There are various inexpensive and simple ways of rewarding contributors in terms of prestige, kudos, and professional recognition; these are particularly important when financial rewards cannot be offered. One of such measures conducted by Neurocirugía (see vol. 17 (1), 2006) ${ }^{15}$ and other journals is the annual publication of the list of collaborators (e.g. referees, with the number of reviews conducted). Another inexpensive measure consists in creating official titles for jobs and functions that are generally conducted by a collaborator -maybe by delegation- without any official recognition. This measure could be put into practice by issuing suitable certificates indicating the conducted tasks, and it would also require an appropriate recognition of such contributions when found in someone's curriculum vitae. This kind of measures are vital to ensure the continuity of the review process, and are therefore necessary to secure the future of the Journal.

\section{Will the printed and the electronic edition of the journal continue to coexist?}

Many readers prefer reading and working with printed documents rather than looking at a computer screen. Furthermore, working with electronic documents requi- rescomputer equipment and skills that not everyone has (though these are both increasingly necessary and very common nowadays) ${ }^{4}$. Whilst electronic documents can easily be printed, the result produced does not offer the quality and binding of a printed edition. It is also likely that subscribers and regular readers will want to keep enjoying the quality of the printed edition, and see their personal library grow. There are also various institutions and libraries that request the printed version of the Journal, and it seems plausible that they will continue to do so at least for some time ${ }^{16}$. Moreover, the printed edition of the Journal is distributed to every member of the Spanish Society of Neurosurgery, so it constitutes a means of communication and access for this organisation. The printed edition is a forum with a very high impact on professional neurosurgeons, especially in Spain; this enables the Journal to obtain sufficient income from advertising to cover a significant part of its costs. Thus, it seems likely that the printed edition of Neurocirugía will remain with us for long.

Nowadays the printed and the electronic version of the Journal offer the same contents. Printed documents are usually more pleasant and convenient to read, whereas electronic access provides greater advantages in the processes of finding, accessing, and retrieving papers. The usual place to conduct a literature review used to be the library, but nowadays this important aspect of research is often carried out with a computer connected to the Internet, and physical location is almost irrelevant. The Internet often eliminates the need to leave the usual workplace to find the most relevant literature, and it also eliminates the long waits and time-consuming trips traditionally required to access its content. For occasional readers and for researchers trying to locate papers by topic or keyword, the electronic edition is of inestimable value.

The most important question for the future coexistence of the two formats of the Journal is whether the electronic version should remain a mere reproduction of the printed edition, or whether it should rather incorporate additional material. A related question is that posed by Lobato et al. ${ }^{15}$ on the potential reduction of the printed edition in favour of the electronic one.

The electronic edition can accommodate additional material at hardly any extra cost. For instance, journals that publish papers in several languages, like Neurocirugia, can give authors the opportunity to publish full versions of their papers online in as many languages as they deem appropriate. Thus, in addition to keeping the option to publish in Spanish or English in the printed edition (as proposed by Lobato et al. $)^{15}$, the Journal could also allow for Spanish and English in the electronic edition. This alternative can be desirable for a considerable number of authors and readers, and has the potential to significantly increase the diffusion of a paper, but it would be unfeasible in the printed 
edition due to the associated increase in the number of pages. This paper in particular is available online both in English and Spanish.

An additional advantage of the electronic edition is that it enables the dissemination of material that incorporates dynamism and sound, and permits interaction, e.g. Functional Magnetic Resonance Imaging, PET/CAT, videos of operations, videos of diagnostic tests, animated figures, spinning 3D images, partial views of extensive databases and image repositories, pivot tables, etc. Some representative examples of relevant videos and animations can be found in the digital anatomist interactive atlases of the Structural Informatics Group at the University of Washington (http://www9.biostr.washington.edu/), and in the repository of neurosciences videos of the University of Wisconsin-Madison (http://www.neuroanatomy.wisc.edu/).

Many scientific journals already encourage authors to include multimedia material as part of their submission (e.g. see the section Operative Nuances of Neurosurgery), and some journals are available exclusively online (Tenopir and King ${ }^{20}$ counted more than 1000 scientific journals available only in electronic format in 2001).

We predict that as the development, access and use of multimedia material becomes simpler and more widespread, an increasing number of electronic papers will appear with functionality that will get lost if printed on paper. In many cases the printed edition will only be able to provide just a fraction of the information and functionality available electronically. At that stage some journals may decide to drastically reduce (perhaps to a collection of abstracts) or even withdraw their printed edition. However, for this to happen, there would need to be both a sustained supply (from authors) and a significant demand (from readers) for multimedia material in scientific papers; until then, both formats are likely to coexist.

\section{Conclusions}

Electronic publishing allows Neurocirugía to offer something that was not economically feasible before: free access to its published papers. An analysis of the costs and interests for the different stakeholders (authors, readers, the Journal, the Spanish Society of Neurosurgery, and society as a whole) indicates that free online access (the current policy of Neurocirugía) is a desirable strategy for all the stakeholders. Many other journals and scientific institutions are also working to facilitate access to research; on many occasions they provide not only free access to papers, but also rights to reproduce published material with the sole condition of properly acknowledging the original authorship.

The printed edition of Neurocirugía still offers some features that justify its current existence: it does not pres- ent technological barriers, its format and printed quality is highly valued by some readers, it is a vehicle of communication for the Neurosurgical Spanish Society, and it provides income from advertising.

The electronic version of the Journal enables the use of several features that have not been fully exploited yet and that cannot be provided in the printed version: sound, movement, interactivity, large amounts of searchable data, results of new diagnostic tests... Sooner or later this will mean different contents in the printed and electronic editions of the Journal, and, in the long run, it may imply revising the design and perhaps even the existence of the printed edition.

\section{Acknowledgements}

We would like to thank Lorraine Robertson, Phillip Newell and Mary Luz Izquierdo for their helpful and constructive comments and suggestions.

\section{References}

1. Bonn, S.M., Lougee, W.P., MacKie-Mason, J.K., Riveros, J.F.: A Report on the PEAK Experiment. D-Lib Magazine 1999; 5 (6). http://www.dlib.org/dlib/june99/06bonn.html

2. Bradie, M., Harms, W.: Evolutionary Epistemology. The Stanford Encyclopedia of Philosophy (Spring 2004 Edition), Edward N. Zalta (ed.). http://plato.stanford.edu/archives/ spr2004/entries/epistemology-evolutionary

3. Buckholtz, A.: Returning Scientific Publishing to Scientists. The Journal of Electronic Publishing 2001; 7 (1). http: //www.press.umich.edu/jep/07-01/buckholtz.html

4. Calatayud Maldonado, V.: What the neurosurgeon of the 21 st century ought to be like. Neurocirugía 2004; 15: 433-438. http://revistaneurocirugia.com/web/artics/v15n5/1.pdf

5. Dawkins, R.: The Selfish Gene, $2^{\text {nd }}$ ed. New York: Oxford University Press, 1989.; pp. 189-201.

6. Editorial: La entrada de NEUROCIRUGIA en la base de datos Index Medicus / MEDLINE. Neurocirugía 2002; 13: 4-5. http://www.revistaneurocirugia.com/web/artics/v13n1/0.pdf

7. Editorial. Neurocirugía 2006; 17: 87-88. http://www.revistaneurocirugia.com/web/artics/v17n2/editorial.pdf

8. Editorial: Not-so-deep impact. Nature 2005; 435(7045): 1003-1004.

9. De Granda Orive, J.I.: Reflections on the Impact Factor. Archivos de Bronconeumología 2003; 39: 409-417. http://www.archbronconeumol.org/cgi-bin/wdbcgi.exe/abn/ abneng.mrevista.fulltext?pident $=13051513$

10. Harnad, S., Brody, T.: Comparing the Impact of Open Access (OA) vs. Non-OA Articles in the Same Journals. DLib Magazine 2004; 10 (6). http://www.dlib.org/dlib/june04/ harnad/06harnad.html

11. Ibáñez, J.: La evolución del factor de impacto de 
Neurocirugía en su contexto nacional e internacional. Neurocirugía 2006; 17:98-101.http://revistaneurocirugia.com/ web/artics/v17n2/2.pdf

12. Ibáñez, J., Sahuquillo, J., Poca, M.A., Arikan, F., Rubio, E.: La incorporación de Neurocirugía al Journal of Citation Reports: análisis bibliométrico de la producción científica neuroquirúrgica española. Neurocirugía 2000; 11: 329350. http://revistaneurocirugia.com/web/artics/artic19.pdf

13. Illingworth, R.: Fraud and other misconduct in biomedical research. Neurocirugía 2005; 16: 297-300. http: //revistaneurocirugia.com/web/artics/v16n4/editorial.pdf

14 Lawrence, S.: Free online availability substantially increases a paper's impact. Nature 2001; 411: 521-521. http://www.nature.com/nature/journal/v411/n6837/ full/411521a0.html

15. Lobato, R.D., González, P., Gómez, P.A., Alday, R., Lagares, A., Alen, J.F.: El cambio en el proceso editorial de la revista Neurocirugía. Neurocirugía 2006; 17: 89-97. http: //www.revistaneurocirugia.com/web/artics/v17n2/1.pdf

16. Odlyzko, A.: The Economics of Electronic Journals. Fistmonday 1997; 2(8). http://www.firstmonday.dk/issues/ issue2_8/odlyzko/index.html

17. Roberts, P.: Scholarly Publishing, Peer Review and the Internet. Fistmonday 1999; 4 (4). http://www.firstmonday.dk/ issues/issue4_4/proberts/index.html

18. Sahuquillo, J.: Sobre la "impactolatría" y otras perversiones científicas. Neurocirugía 2006; 17: 102-104. http: //revistaneurocirugia.com/web/artics/v17n2/3.pdf

19. Seglen, P. O.: Why the impact factor of journals should not be used for evaluating research. British Medical Journal 1997; 314 (7079) 497-498. http://bmj.bmjjournals.com/cgi/ content/full/314/7079/497

20. Tenopir, C., King, D.W.: Lessons for the future of journals. Nature 2001; 413: 672 - 674. http:/www.nature.com/ nature/debates/e-access/Articles/tenopir.html

21. Varian, H.R.: Pricing Electronic Journals. D-Lib Magazine 1996; 2 (6). http://www.dlib.org/dlib/june96/ 06varian.html

22. Varian, H.R.: The Future of Electronic Journals. The Journal of Electronic Publishing 1998; 4 (1). http:// www.press.umich.edu/jep/04-01/varian.html

Izquierdo, S.S.; Izquierdo, L.R.; Izquierdo, J.M.: Publishing science in the digital age. The case of Neurocirugía. Neurocirugía 2007; 18: 193-200.

Corresponding author: Segismundo Izquierdo Millán. ETS. Ingenieros Industriales. $\mathrm{P}^{\mathrm{o}}$ del cauce s/n. 47011 Valladolid. 